\title{
LPS-induced iNOS expression in N9 microglial cells is suppressed by geniposide via ERK, p38 and nuclear factor- $\kappa \mathrm{B}$ signaling pathways
}

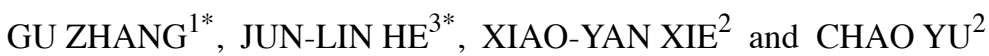 \\ ${ }^{1}$ Department of Pathology, Zhejiang Cancer Hospital, Zhejiang 310022; ${ }^{2}$ Institute of Life Sciences and \\ ${ }^{3}$ Laboratory of Reproductive Biology, School of Public Health, Chongqing Medical University, Chongqing 400016, P.R. China
}

Received March 20, 2012; Accepted May 14, 2012

DOI: $10.3892 /$ ijmm.2012.1030

\begin{abstract}
Activated microglia producing reactive nitrogen species, inflammatory factors, reactive oxygen species (ROS) and other neurovirulent factors, can lead to the development of neurodegenerative diseases. Certain compounds can inhibit the activation of microglia. However, the mechanisms remain unclear. In the present study, we investigated the inhibitory effect of geniposide on the production of ROS and inducible nitric oxide synthase (iNOS) in lipopolysaccharide (LPS)stimulated N9 murine microglial cells through the p38, ERK1/2 and nuclear factor- $\kappa \mathrm{B}(\mathrm{NF}-\kappa \mathrm{B})$ signaling pathways. After the N9 cells were pre-treated with the vehicle or geniposide and exposed to LPS for the time indicated, the MTT conversion test was used to assess cell viability. Suitable concentrations were chosen and adjusted according to the experiments. Extracellular nitric oxide (NO) release was measured by Griess reaction. The formation of ROS and intracellular NO was evaluated by fluorescence imaging. NOS activities were determined using commercially available kits. The morphology of the N9 cells was examined by hematoxylin and eosin staining. The expression of iNOS mRNA was examined by RT-PCR. The protein levels of iNOS, p38 mitogen-activated protein kinase (MAPK), ERK1/2 and NF- $\kappa$ B, inhibitory factor $-\kappa B-\alpha($ I $\kappa$ B- $\alpha)$ were determined by western blot analysis. The results showed that geniposide attenuated the activation of N9 cells and inhibited
\end{abstract}

Correspondence to: Professor Chao Yu, Institute of Life Sciences, Chongqing Medical University, No. 1 Yi Xue Yuan Road, Chongqing 400016, P.R. China

E-mail: yuchaom@163.com

*Contributed equally

Abbreviations: NO, nitric oxide; iNOS, inducible nitric oxide synthase; ROS, reactive oxygen species; LPS, lipopolysaccharide; MAPK, mitogen-activated protein kinase; NF- $\kappa \mathrm{B}$, nuclear factor- $\kappa \mathrm{B}$

Key words: geniposide, N9 murine microglial cells, lipopolysaccharide, inducible nitric oxide synthase, nuclear factor- $\kappa \mathrm{B}$, mitogen-activated protein kinase the overproduction of NO, intracellular ROS and the expression of iNOS induced by LPS in the cells. In addition, geniposide blocked the phosphorylation of $\mathrm{p} 38$, ERK1/2 and inhibited the drop-off of I $\kappa \mathrm{B}$ induced by LPS in the cells. These data indicate that geniposide has therapeutic potential for the treatment of neurodegenerative diseases, and that it exerts its effects by inhibiting inflammation.

\section{Introduction}

Microglia, differentiated from the active phagocytic amoeboid monocytes $(1,2)$, are brain resident immunocompetent cells originating from bone marrow-derived monocytes that invade the brain during embryogenesis. Activated microglia produce factors, such as reactive nitrogen species (RNS), inflammatory factors, reactive oxygen species (ROS) and any other neurovirulent factors, which injure neurons and result in neurodegenerative diseases, such as Parkinson's disease (PD) or Alzheimer's disease (AD) $(3,4)$. The considerable contribution of microglial activation as a risk factor to the pathogenesis of PD has previously been proposed (5-7). Several factors have been identified and are known to provoke microglial activition. Lipopolysaccharide (LPS), the major portion of the outer membrane of Gram-negative bacteria, is regarded as the main risk factor responsible for microglial activation (8-10). Among the LPS-induced reactions, the overproduction of nitric oxide (NO) generated by NO synthase (NOS) has received much attention in activated microglia. Inducible NOS (iNOS) is the most important NOS involved in microglial activation. In a physiological microenvironment, NO causes vasoconstriction, acts as a neuroendocrine mediator in the central nervous system (CNS), and has protective functions in anti-inflammatory pathways. Elevated NO levels may also be beneficial in response to immunological stimuli as a defense mechanism against microbial or viral insults. Additionally, NO can also be produced in response to factors resulting from chronic inflammatory conditions, such as PD and AD (11).

Geniposide, one of the major iridoid glycosides in fruits (12), has been used in folk medicine in certain countries due to its antitumor $(13,14)$ and anti-oxidative activities (15). Currently, geniposide is known for its neuritogenic and neuroprotective actions (16) and is suggested for the treatment of neurodege- 
nerative disorders. It has been demonstrated that geniposide may reduce neuroinflammation and repress brain microglial activation (17). However, the mechanism involved remains unclear.

In the present study, we explored the effects of geniposide on microglial activation. Our data demonstrate that geniposide attenuates the production of ROS, NO and iNOS by blocking the phosphorylation of $\mathrm{p} 38$, ERK1/2 and nuclear factor- $\kappa \mathrm{B}$ $(\mathrm{NF}-\kappa \mathrm{B})$ induced by LPS in N9 cells. Thus, the present study delivers important new insights into the molecular pathways that may contribute to the proposed beneficial effects of geniposide in the treatment of neurodegenerative disorders.

\section{Materials and methods}

Chemicals and reagents. Geniposide was obtained from Chengdu Push Biotechnology Co., Ltd. (Chengdu, China). LPS, 2',7'-dichlorofluorescein diacetate (DCFH-DA), 3-(4,5dimethylthiazol-2-yl)-2,5-diphenyltetrazolium bromide (MTT), and $\beta$-mercaptoethanol were purchased from Sigma (St. Louis, MO, USA). The ERK1/2 inhibitor (PD98059) and p38 inhibitor (SB203580) were obtained from Invitrogen (Carlsbad, CA, USA). Reagent kits used for the measurement of NOS and extracellular NO were obtained from the Nanjing Jiancheng Bioengineering Institute (Nanjing, China). 3-Amino,4aminomethyl-2',7'-difluorescein diacetate (DAF-FM DA) and hematoxylin and eosin (H\&E) were acquired from the Beyotime Institute of Biotechnology (Jiangsu, China). Iscove's modified Dulbecco's medium (IMDM), fetal bovine serum (FBS) and antibiotics (penicillin/streptomycin) were purchased from Gibco-BRL (Rockville, MD, USA). TRIzol was obtained from Sangon Biological Engineering Technology and Services

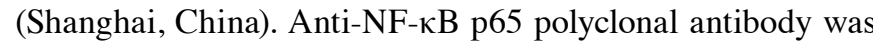
purchased from the Beyotime Institute of Biotechnology. Antiinhibitory factor- $\kappa \mathrm{B}-\alpha(\mathrm{I} \kappa \mathrm{B}-\alpha)$, anti-p38, anti-phospho-p38 (p-p38), anti-ERK1/2, anti-phospho-ERK1/2 (p-ERK1/2) and anti- $\beta$-actin polyclonal antibodies were purchased from Santa Cruz Biotechnology, Inc. (Santa Cruz, CA, USA). Anti-iNOS antibody was supplied from Cell Signaling Technology, Inc. (Boston, MA, USA).

Cell culture and treatment. The N9 murine microglial cell line was a gift from Dr Yun Bai (Third Military Medical University, Chongqing, China). The cells were cultured in IMDM supplemented with $10 \%$ FBS, $50 \mu \mathrm{M} \beta$-mercaptoethanol, penicillin $(100 \mathrm{U} / \mathrm{ml})$ and streptomycin $(100 \mu \mathrm{g} / \mathrm{ml})$ and maintained at $37^{\circ} \mathrm{C}$ with $5 \% \mathrm{CO}_{2}$ in a humidified incubator. Pancreatin $(0.25 \%)$ was used to digest and passage the culture. The N9 microglial cells were plated into 6-well plates for most of the experiments. When the cells reached subconfluence they were pre-treated for $24 \mathrm{~h}$ with IMDM culture medium containing various concentrations of geniposide. The cells were then exposed to LPS $(1 \mu \mathrm{g} / \mathrm{ml})$ diluted in culture medium for $4 \mathrm{~h}$ at $37^{\circ} \mathrm{C}$ after washing twice with phosphate-buffered saline (PBS, pH 7.4).

Cell viability assay. The MTT conversion test was used to assess the cell viability (18). N9 microglial cells were seeded at a density of $7.5 \times 10^{3}$ cells/well in 96-well plates containing $150 \mu \mathrm{l}$ of IMDM medium with $10 \%$ FBS and grown to subconfluence.
The cells then received $150 \mu \mathrm{l}$ of IMDM medium with $10 \%$ FBS plus various concentrations of geniposide (1, 10, 100 and $200 \mu \mathrm{g} / \mathrm{ml})$ or LPS $(10,100$ and 1,000 $\mathrm{ng} / \mathrm{ml})$ and were incubated for $24 \mathrm{~h}$, respectively. The cells were then washed with PBS (pH 7.4) and incubated with MTT $(5 \mathrm{mg} / \mathrm{ml})$ in a culture medium for $3 \mathrm{~h}$ at $37^{\circ} \mathrm{C}$. The medium was discarded and the formazan blue, which formed in the cells, was dissolved in $100 \mu \mathrm{l}$ of DMSO. The optical density at $490 \mathrm{~nm}$ was determined with a Sunrise Remote Microplate Reader (Grodig, Austria). Cell viability in each well was presented as percentage of the control level (treated with the vehicle).

Preparations of RNA extraction and reverse transcriptionpolymerase chain reaction ( $R T-P C R)$. Total-RNA was extracted using TRIzol reagent (Takara, Inc., Dalian, China) according to the manufacturer's instructions and RNA concentration was determined using a DNA/RNA GeneQuant Calculator (from Amersham Biosciences, Piscataway, NJ, USA). Reverse transcription was carried out in $10 \mu \mathrm{l}$ of the reaction mixture containing $1 \mu \mathrm{g}$ of total RNA, 25 pmol of oligo(dT) primer, $10 \mathrm{nmol}$ of dNTP mixture, 20 units of RNase inhibitor and 2.5 units of AMV reverse transcriptase (Bioer Technology Co., Hangzhou, China) at $42^{\circ} \mathrm{C}$ for $1 \mathrm{~h}$. PCR amplification was performed in $20 \mu \mathrm{l}$ PCR reaction mixture containing $1 \mu \mathrm{l}$ of cDNA reaction mixture, $10 \mathrm{nmol}$ of dNTP mixture, $10 \mathrm{pmol}$ of upstream and downstream primers and 2 units of BioReady rTaq polymerase (Bioer Technology Co.). PCR amplification to detect differences among the samples was set as follows: $4 \mathrm{~min}$ at $94^{\circ} \mathrm{C}$ for initial denaturation, 30 cycles $\mathrm{x} 30 \mathrm{sec}$ at $94^{\circ} \mathrm{C}, 45 \mathrm{sec}$ at $53^{\circ} \mathrm{C}$, and $45 \mathrm{sec}$ at $72^{\circ} \mathrm{C}$ for iNOS; 30 cycles x $30 \mathrm{sec}$ at $94^{\circ} \mathrm{C}, 30 \mathrm{sec}$ at $54^{\circ} \mathrm{C}$, and $30 \mathrm{sec}$ at $72^{\circ} \mathrm{C}$ for $\beta$-actin. Primers used were: $\beta$-actin (386 bp) upstream, $5^{\prime}$-GATGGT GGGAATGGGTCAGA-3' and downstream, 5'-GGAGAGCA TAGCCCTCGTAGAT-3'; iNOS (650 bp) upstream, 5'-TGGA GCGAGTTGTGGATTGTC-3' and downstream, 5'-CCCTTT GTGCTGGGAGTCAT-3'. The PCR product was electrophoresed on a $1.5 \%$ agarose gel containing $0.1 \mu \mathrm{g} / \mathrm{ml}$ dye (GoldView; SBS Genetech Co., Beiing, China). Gels were visualized and photographed by a Gel Doc 2000 image analyzer (Bio-Rad, Hercules, CA, USA). $\beta$-actin was used for normalization. The ratios of the emissions incorporated into the PCR products of the examined gene to the $\beta$-actin products were calculated to evaluate relative changes in the mRNA expression levels of the examined genes.

Western blot analysis. For isolation of total cell extracts, treated N9 cells were washed twice in ice-cold PBS and lysed with RIPA lysis buffer (50 mM Tris with $\mathrm{pH} 7.4,150 \mathrm{mM} \mathrm{NaCl}$, $1 \%$ Triton $\mathrm{X}-100,1 \%$ sodium deoxycholate, $0.1 \%$ SDS and $0.05 \mathrm{mM}$ EDTA). Samples were centrifuged at $12,000 \mathrm{x} \mathrm{g}$ for $15 \mathrm{~min}$ at $4^{\circ} \mathrm{C}$ and the supernatant was collected as total cell lysate. Nuclear and cytoplasmic protein were extracted with the Nuclear and Cytoplasmic Protein Extraction kit according to the manufacturer's instructions (Beyotime Institute of Biotechnology). Protein concentrations were determined using the Bicinchoninic Acid Protein Assay kit (Beyotime Institute of Biotechnology). The cell lysates with 5X loading buffer $(125 \mathrm{mM}$ Tris-HCl, $\mathrm{pH} 6.8,10 \%$ SDS, $8 \%$ dithiothreitol, $50 \%$ glycerol and $0.5 \%$ bromochlorophenol blue) were boiled for $10 \mathrm{~min}$, and $50 \mu \mathrm{g}$ of protein were loaded per lane 
on $8-12 \%$ SDS-polyacrylamide gels. Proteins were separated and transferred to $0.45 \mu \mathrm{m}$ polyvinylidene fluoride membranes. Membranes were blocked with 5\% skim milk in PBS with $0.1 \%$ Tween-20 (PBST) for $1 \mathrm{~h}$. Primary antibodies against iNOS, NF-кB, IкB- $\alpha$, p38, p-p38, ERK1/2, p-ERK1/2 and $\beta$-actin in PBST were incubated with membranes overnight at $4^{\circ} \mathrm{C}$. The membranes were then washed in PBST 3 times and incubated with the bound horseradish peroxidase-conjugated secondary antibody for $1 \mathrm{~h}$. After the final wash, protein bands were developed using enhanced chemiluminescence reagents and densitometric analysis was performed with the ChemDoc System (Bio-Rad).

Measurement of intracellular ROS formation. Intracellular ROS formation was assessed based on the ROS-mediated conversion of non-fluorescent DCFH-DA into DCFH, as the fluorescence intensity of DCFH reflects enhanced oxidative stress. Briefly, cells seeded in black 6-well plates were washed twice with PBS ( $\mathrm{pH} 7.4$ ) and were pre-incubated with various concentrations of geniposide $(20,40,80$ and $160 \mu \mathrm{g} / \mathrm{ml})$ for $24 \mathrm{~h}$. Thereafter, cells were washed twice with (PBS, pH 7.4) and then exposed to $1 \mu \mathrm{g} / \mathrm{ml}$ of LPS for $4 \mathrm{~h}$ and incubated in PBS containing $20 \mu \mathrm{M}$ of DCFH-DA at $37^{\circ} \mathrm{C}$ for $2 \mathrm{~h}$ in the dark. Subsequently, the fluorescence of cells in each well was measured at an excitation wavelength of $485 \mathrm{~nm}$ and an emission wavelength of $530 \mathrm{~nm}$ using a FLx800 fluorescence microplate reader (Bio-Tek Instruments, Inc., Winooski, VT, USA). Fluorescence values were calculated after subtracting background fluorescence levels, as measured under identical conditions but without DCFH-DA.

Flow cytometry for the measurement of intracellular NO formation. The production of intracellular NO in N9 microglial cells was evaluated using the NO-specific fluorescent dye, DAF-FM DA, as described previously (19). Cells seeded in 6-well plates were detached by $0.125 \%$ EDTA-free trypsin and suspended in PBS (pH 7.4) containing $5 \mu \mathrm{M}$ of DAF-FM DA at $37^{\circ} \mathrm{C}$ for $20 \mathrm{~min}$. The cells were then washed 3 times and re-suspended with PBS (pH 7.4). The fluorescence in the cells was quantitatively analyzed at an emission wavelength of $515 \mathrm{~nm}$ and an excitation wavelength of $495 \mathrm{~nm}$ using a Vantage SE flow cytometer system (Becton-Dickinson, San Jose, CA, USA).

Analysis of NOS activity. For the assay activity of NOS, cells were seeded in 6 -well plates $\left(2 \times 10^{5}\right.$ cells/well $)$ and treated as previously described. Cells were washed and immediately mixed with ice-cold RIPA lysis buffer. The homogenate was centrifuged at $12,000 \mathrm{x} \mathrm{g}$ at $4^{\circ} \mathrm{C}$ for $15 \mathrm{~min}$. The supernatant was harvested and stored at $-80^{\circ} \mathrm{C}$. The protein content was detected by the bicinchoninic acid (BCA) method, using bovine serum albumin as a reference standard. NOS activities were all determined using commercially available kits. All procedures completely complied with the manufacturer's instructions. Briefly, NOS activities was determined at $530 \mathrm{~nm}$ by the reaction of NO with nucleophiles to form a chromophoric production.

Measurement of extracellular $\mathrm{NO}$ release. The concentration of nitrites $\left(\mathrm{NO}_{2}^{-}\right)$and nitrates $\left(\mathrm{NO}_{3}^{-}\right)$, stable end products of $\mathrm{NO}$, were determined by the Griess reaction as previously described (20). NO production in the culture medium was determined by measuring the optical density at $550 \mathrm{~nm}$ and expressed as units/milligram protein.

$H \& E$ staining. Cells were seeded in 6-well plates $\left(2 \times 10^{5}\right.$ cells/ well) and placed in a little glass to form a cell climbing slice. The cells were fixed in $4 \%$ formaldehyde for $20 \mathrm{~min}$, and then rinsed in PBS for $1 \mathrm{~min}$. The cells were incubated for $10 \mathrm{~min}$ in hematoxylin solution. Subsequently, the cells were incubated in $\mathrm{HCl}$-ethanol (1\%) for $10 \mathrm{sec}$. Subsequent rinsing was followed by incubation in eosin for $1.5 \mathrm{~min}$. The specimens were covered with coverslips and were visualized and photographed under a microscope.

Statistical analysis. Each experiment was performed at least 3 times. The data are expressed as the means \pm standard deviation, analyzed using the SPSS 11.0 software. The differences between the 2 groups were analyzed using the Student's t-test. Differences in the data between 2 or more groups were analyzed by the analysis of variance method. $\mathrm{P}<0.05$ indicated that the differences were statistically significant.

\section{Results}

Scavenging effect of geniposide on the extracellular and intracellular NO production induced by LPS in N9 microglial cells. To investigate the effect of geniposide on LPS-induced extracellular NO production in N9 microglial cells, the cell culture medium was harvested and the concentration of accumulated nitrite, the oxidative product of NO, was determined by the Griess method. The cells were pre-treated with various concentrations of geniposide $(20,40,80$ and $160 \mu \mathrm{g} / \mathrm{ml})$ for $20 \mathrm{~h}$ and then co-treated with LPS $(1 \mu \mathrm{g} / \mathrm{ml})$ for $4 \mathrm{~h}$. The results indicated that extracellular NO induced by LPS in N9 cells increased by 22-fold compared to the vehicle-treated control group $(\mathrm{P}<0.05)$ (Fig. 1A). By contrast, pre-treatment with geniposide for $4 \mathrm{~h}$ before exposure to LPS suppressed the production of NO in a dose-dependent manner.

In addition, we assessed intracellular NO by monitoring the changes in fluorescence intensity. Intracellular NO in N9 cells increased by 3 -fold in response to LPS as compared to the controls. The cells that were pre-treated with geniposide before exposure to LPS also showed suppressed intracellular NO levels in a dose-dependent manner (Fig. 1B). These data illustrate that geniposide attenuates increasing NO levels induced by LPS in cells.

Effect of geniposide on NOS activity induced by LPS in N9 microglial cells. NO was generated by NOS. To investigate the activity of NOS, we used commercially available kits as described in Materials and methods. The cells were pretreated with geniposide $(20,40,80$ and $160 \mu \mathrm{g} / \mathrm{ml})$ for $20 \mathrm{~h}$ and then exposed to LPS $(1 \mu \mathrm{g} / \mathrm{ml})$ for $4 \mathrm{~h}$. The activity of NOS induced by LPS was reduced by geniposide in a dosedependent manner in the N9 cells (Fig. 2). These results demonstrate that geniposide suppresses the production of NO by inhibiting NOS activity.

Effect of geniposide on iNOS production induced by LPS in N9 microglial cells. iNOS plays an important role in generating the 

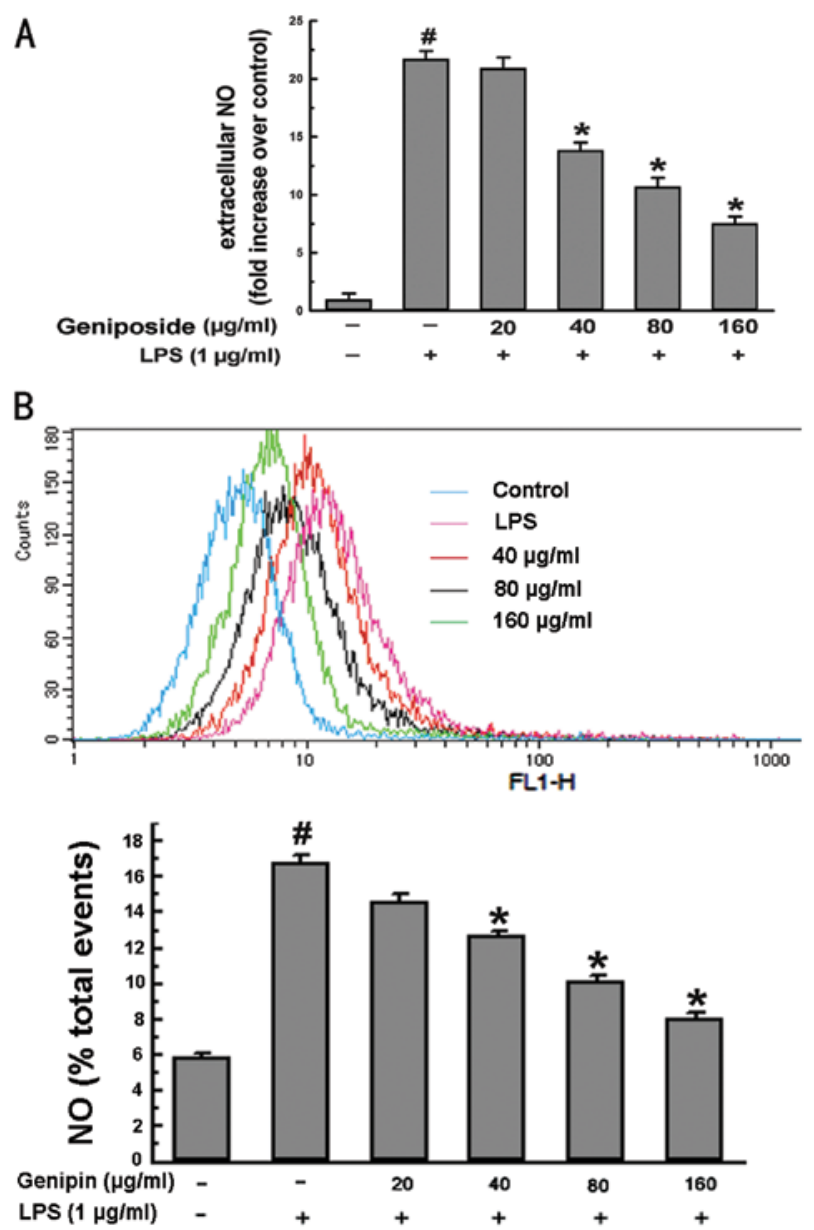

Figure 1. Effect of geniposide on the extracellular and intracellular NO production levels induced by LPS in N9 cells. Cells were pre-treated with geniposide $(20-160 \mu \mathrm{g} / \mathrm{ml})$ for $20 \mathrm{~h}$ and then co-treated with LPS $(1 \mu \mathrm{g} / \mathrm{ml})$ for $4 \mathrm{~h}$. (A) The extracellular NO levels in the culture medium were measured by Griess reaction. (B) Intracellular NO levels were measured using flow cytometry. Data are representative of 3 experiments (means $\pm \mathrm{SD}$ ). ${ }^{\text {}} \mathrm{P}<0.05$, compared to the vehicle-treated control group; ${ }^{*} \mathrm{P}<0.05$, compared to the group treated with LPS alone.

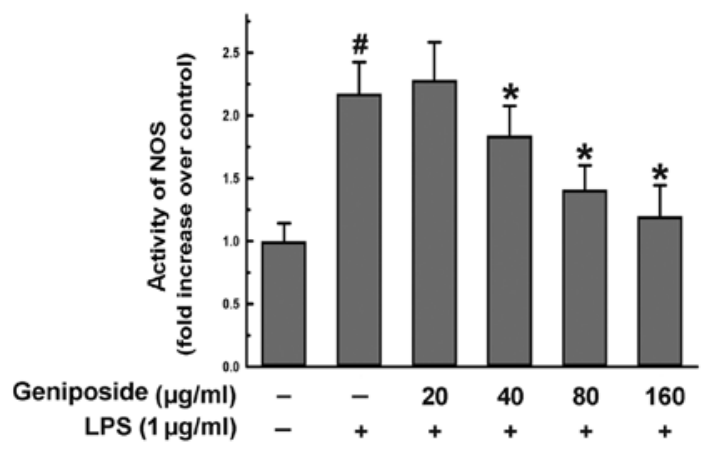

Figure 2. Effect of geniposide on the activity of NOS induced by LPS in N9 microglial cells. Cells were pre-treated with geniposide $(20,40,80$ and $160 \mu \mathrm{g} / \mathrm{ml})$ for $20 \mathrm{~h}$ and then exposed to LPS $(1 \mu \mathrm{g} / \mathrm{ml})$ for $4 \mathrm{~h}$. The activity of NOS was determined using commercially available kits. Data are representative of 3 experiments (means $\pm \mathrm{SD}$ ). ${ }^{*} \mathrm{P}<0.05$, compared to the vehicle-treated control group. ${ }^{*} \mathrm{P}<0.05$, compared to the group treated with LPS alone.

production of NO in cells. The expression of iNOS is usually increased in neuron cells induced by inflammatory factors,
A
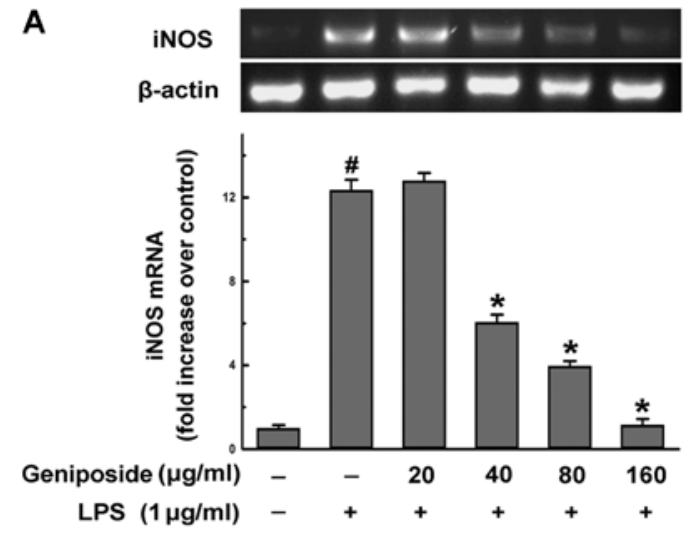

B
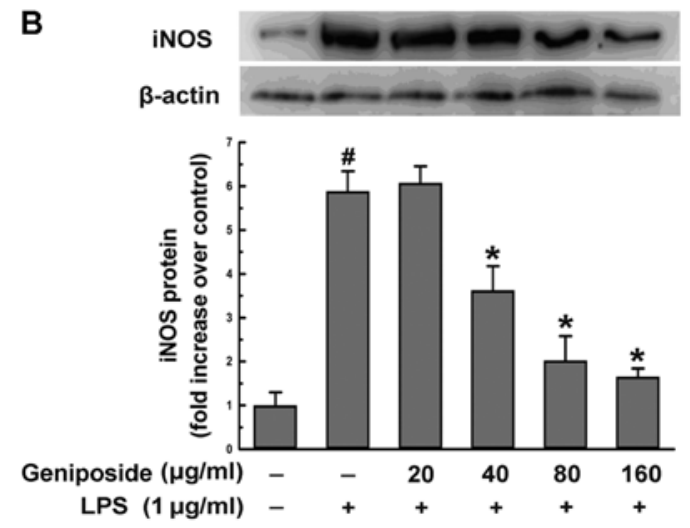

Figure 3. Effect of geniposide on the expression of iNOS in microglia N9 cells induced by LPS. Cells were pre-treated with various concentrations of geniposide $(20,40,80$ and $160 \mu \mathrm{g} / \mathrm{ml})$ for $20 \mathrm{~h}$ and then exposed to LPS (1 $\mu \mathrm{g} / \mathrm{ml}$ ) for $4 \mathrm{~h}$. (A) The iNOS mRNA level was analyzed by RT-PCR. (B) The iNOS protein level was examined by western blot analysis. Data are representative of 3 experiments (means $\pm \mathrm{SD}$ ). ${ }^{\text {"}} \mathrm{P}<0.05$, compared to the vehicle-treated control group. ${ }^{*} \mathrm{P}<0.05$, compared to the group treated with LPS alone.

such as LPS. To explore whether geniposide suppressing the production of NO is associated with the expression of iNOS, we examined the mRNA levels of iNOS by RT-PCR and the protein level of iNOS using western blot analysis. The cells were pre-treated with geniposide $(20,40,80$ and $160 \mu \mathrm{g} / \mathrm{ml})$ for $20 \mathrm{~h}$ and then exposed to LPS $(1 \mu \mathrm{g} / \mathrm{ml})$ for $4 \mathrm{~h}$. The expression of iNOS mRNA induced by LPS was significantly reduced (35.0, 50.8 and $91.7 \%$; $\mathrm{P}<0.05$ ) when geniposide was administered at a concentration of over $40 \mu \mathrm{g} / \mathrm{ml}$ (Fig. 3A). The increased levels of the iNOS protein induced by LPS were reduced by geniposide pre-treatment in a dose-dependent manner (Fig. 3B). Our results demonstrated that the increasing activity of NOS in N9 cells induced by LPS was relative to the expression of iNOS and that geniposide inhibited the upregulated gene expression of iNOS.

Suppressive effect of geniposide on microglial activation induced by LPS. To clarify the effect of geniposide on microglial activation induced by LPS, we observed the change of morphology of the N9 cells by H\&E staining after treatment with different metarials. The cells were pre-treated with various concentrations of geniposide $(20,40,80$ and $160 \mu \mathrm{g} / \mathrm{ml})$ for $20 \mathrm{~h}$ and co-treated with LPS $(1 \mu \mathrm{g} / \mathrm{ml})$ for $4 \mathrm{~h}$. The relatively less microglial activation in the vehicle-treated cells was observed 

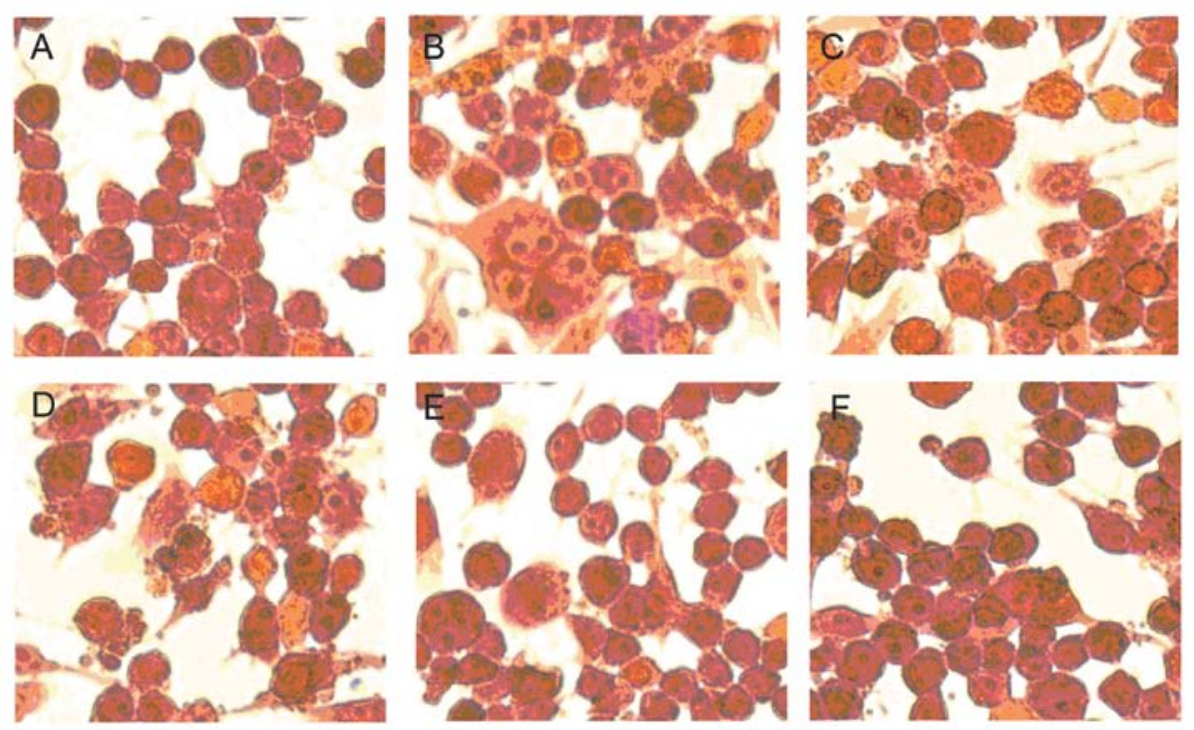

Figure 4. Effect of geniposide on the morphology of microglial activation induced by LPS. (A) H\&E staining of the vehicle-treated cells. (B) Cells stimulated by LPS $(1 \mu \mathrm{g} / \mathrm{ml})$ for $4 \mathrm{~h}$. (C-F) Cells pre-treated with geniposide (20, 40, 80 and $160 \mu \mathrm{g} / \mathrm{ml})$ for $24 \mathrm{~h}$ before LPS (1 $\mu \mathrm{g} / \mathrm{ml})$ exposure, respectively. After treatment, cells were stained with H\&E and then photographed under a microscope. Each experiment was performed 3 times.
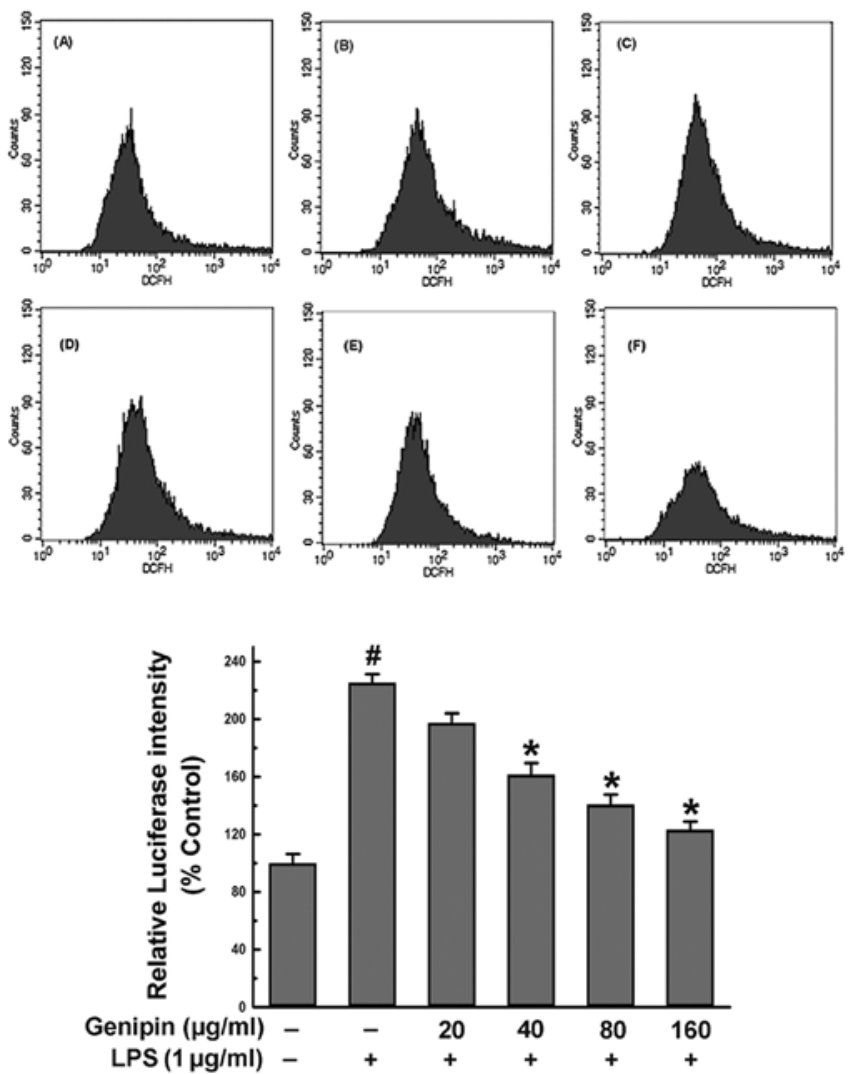

Figure 5. Inhibitory effect of geniposide on the intracellular ROS formation in N9 cells. Cells were pre-treated with geniposide $(20,40,80$ and $160 \mu \mathrm{g} / \mathrm{ml})$ for $20 \mathrm{~h}$ and exposed to LPS $(1 \mu \mathrm{g} / \mathrm{ml})$ for $4 \mathrm{~h}$. Intracellular ROS was assessed by monitoring the changes in fluorescence intensity. Data are representative of 3 experiments (means $\pm \mathrm{SD}$ ). ${ }^{\#} \mathrm{P}<0.05$ compared to the vehicle-treated control group. ${ }^{*} \mathrm{P}<0.05$ compared to the group treated with LPS alone.

(Fig. 4A). By contrast, after being exposed to LPS $(1 \mu \mathrm{g} / \mathrm{ml})$ for $4 \mathrm{~h}$, the cell morphology showed variant cells with an amoeba- like shape (Fig. 4B). It revealed that LPS stimulation induced a marked microglial activation. On the other hand, the microglial activation induced by LPS was suppressed by pre-treatment with geniposide for $24 \mathrm{~h}$ (Fig. 4C-F). These results suggest that geniposide suppresses microglial activation induced by LPS in a dose-dependent manner.

Inhibitory effect of geniposide on intracellular ROS formation in N9 cells. The production of ROS is a risk factor in microglial activation induced by inflammatory factors. Therefore, we assessed intracellular ROS induced by LPS in N9 cells by monitoring the changes in fluorescence intensity of the probe, DCFH-DA (Fig. 5). The results indicated that the amount of cells with fluorescence induced by $1 \mu \mathrm{g} / \mathrm{ml}$ LPS for $4 \mathrm{~h}$ significantly increased by 2.26 -fold compared to the vehicletreated control group $(\mathrm{P}<0.05)$. By contrast, pre-treatment with geniposide for $20 \mathrm{~h}$ before exposure to LPS suppressed the production of DCFH fluorescence in a dose-dependent manner. The suppressive effect of geniposide $(160 \mu \mathrm{g} / \mathrm{ml})$ was considered to be significant $(54.6 \%)$ compared to the group treated with LPS alone $(\mathrm{P}<0.05)$. These results suggest that one of the reasons that geniposide suppresses microglial activation is the decrease in the production of ROS.

Geniposide and LPS treatment display no inhibitory effect on N9 cell viability. To evaluate whether the administered concentration of geniposide or LPS influenced N9 cell viability, the effect of geniposide and LPS on N9 cell viability was determined by MTT assay. The results showed that incubation with LPS (10-1,000 $\mathrm{ng} / \mathrm{ml})$ alone for $24 \mathrm{~h}$ had no effect on the viability of N9 cells (Fig. 6A). Additionally, treatment with geniposide $(1-200 \mu \mathrm{g} / \mathrm{ml})$ for $24 \mathrm{~h}$ showed no inhibitory effect on N9 cell viability in comparison with the vehicle-treated group (Fig. 6B). Thus, the effect of geniposide in preventing microglial activation was not caused by the cytotoxicity of reagents in previous experiments. 
A
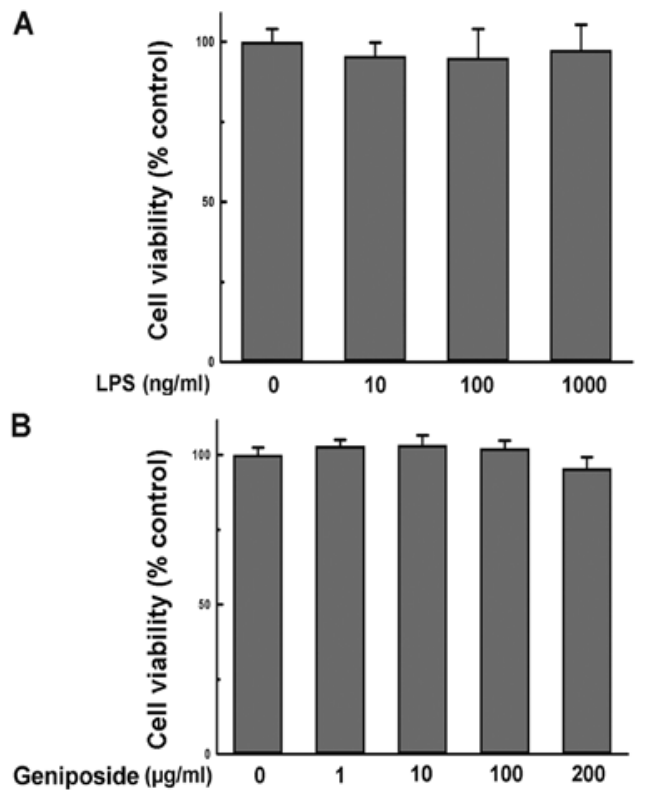

Figure 6. Effect of geniposide and LPS on N9 cell viability evaluated by MTT assay. (A) N9 cells were treated with LPS (10-1,000 ng/ml) and incubated for $24 \mathrm{~h}$. (B) N9 Cells were treated with geniposide $(1-200 \mu \mathrm{g} / \mathrm{ml})$ for $24 \mathrm{~h}$. Values represent the means \pm SD of 3 independent experiments.

Effect of geniposide on the phosphorylation of ERK and p38 mitogen-activated protein kinase (MAPK) induced by LPS in $N 9$ cells. To investigate whether geniposide influences underlying pathways followed by the upregulation of ROS, NO and iNOS levels induced by LPS in microglial cells, we examined the effect of geniposide on LPS-induced p38 and ERK1/2 activation in N9 cells. The cells were pre-treated with geniposide ( 80 and $160 \mu \mathrm{g} / \mathrm{ml})$ for $20 \mathrm{~h}$ and then co-treated with LPS $(1 \mu \mathrm{g} / \mathrm{ml})$ for $30 \mathrm{~min}$. The LPS-induced phosphorylation of p38 (Fig. 7A) and ERK1/2 (Fig. 7B) was inhibited by geniposide. These findings suggested that the phosphorylation of $\mathrm{p} 38$ and ERK1/2 involved in the production of ROS, NO and iNOS induced by LPS was downregulated by geniposide.

Effect of p38 and ERK1/2 inhibitors on iNOS protein expression induced by LPS in $N 9$ cells. To confirm that geniposide suppresses the expression of iNOS induced by LPS in microglial cells via the p38 and ERK 1/2 MAPK signaling pathway, N9 cells were pre-treated with SB203580 $(25 \mu \mathrm{M})$, p38 MAPK inhibitor, or PD98059 $(30 \mu \mathrm{M})$, ERK1/2 inhibitor, for $1 \mathrm{~h}$ and exposed to LPS $(1 \mu \mathrm{g} / \mathrm{ml})$ for $20 \mathrm{~h}$. Treatment with LPS for $20 \mathrm{~h}$ induced a remarkable upregulation of the iNOS protein level in N9 cells (Fig. 8). By contrast, the iNOS protein level decreased significantly following pre-treatment with SB203580 or PD98059 $(\mathrm{P}<0.05)$ compared to the LPS-treated group. The iNOS protein level was not decreased when N9 cells were treated with SB203580 or PD98059 alone compared to the vehicle-treated group (Fig. 8).

Geniposide inhibits liberation of $\mathrm{I} \kappa \mathrm{B}$ from $\mathrm{NF}-\kappa \mathrm{B}$ complex and suppresses $N F-\kappa B$ translocation into nucleus induced by LPS in $N 9$ cells. To determine whether the downregulation of ROS, NO and iNOS levels in microglial cells is regulated by the NF- $\mathrm{KB}$ signaling pathway, we examined the NF- $\mathrm{kB}$ levels in the nucleus and endochylema in N9 cells, respectively, and
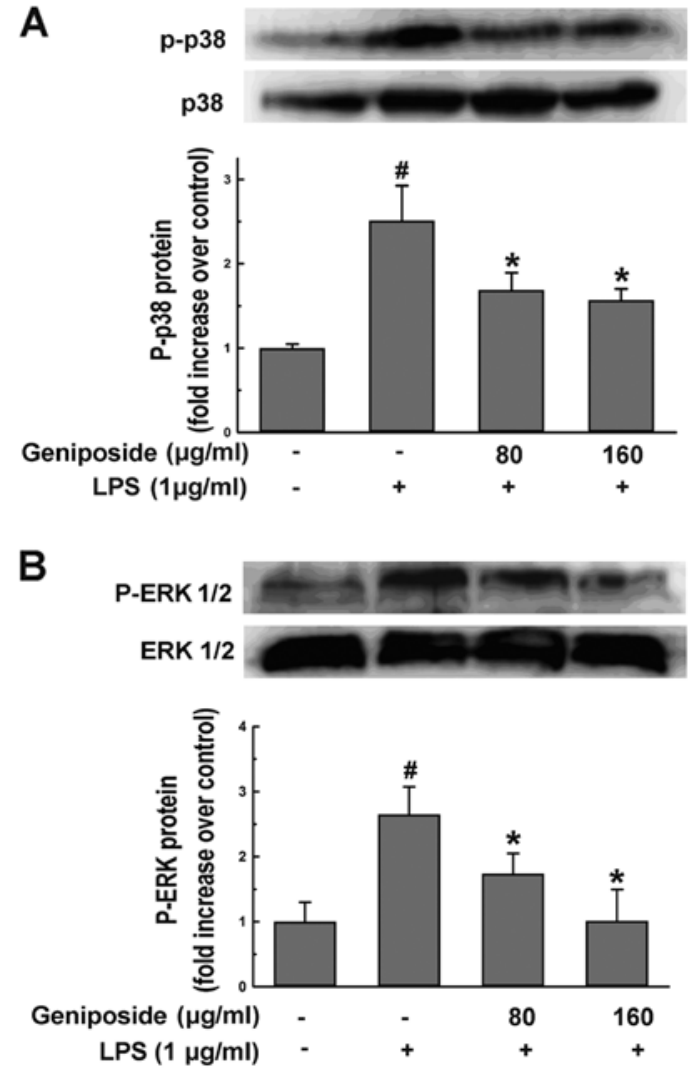

Figure 7. Effect of geniposide on the phosphorylation of ERK and p38 MAPK induced by LPS in N9 cells. The cells were pre-treated with geniposide (80 and $160 \mu \mathrm{g} / \mathrm{ml})$ for $24 \mathrm{~h}$ and co-treated with LPS $(1 \mu \mathrm{g} / \mathrm{ml})$ for 30 min. (A) The protein levels of phosphorylated p38 and (B) ERK1/2 were evaluated by western blot analysis. Data are representative of 3 experiments (means $\pm \mathrm{SD}$ ). ${ }^{*} \mathrm{P}<0.05$ compared to the vehicle-treated control group. ${ }^{*} \mathrm{P}<0.05$ compared to the group treated with LPS alone.

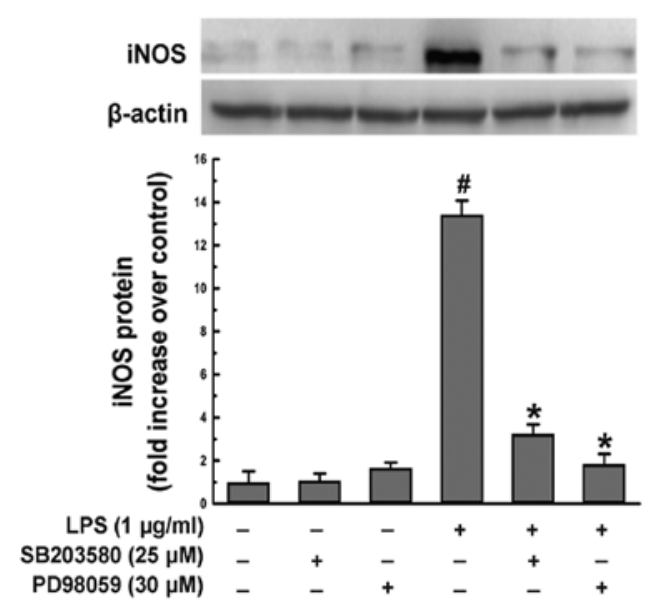

Figure 8. Effect of p38 and ERK inhibitors on the expression of iNOS induced by LPS in N9 cells. The N9 cells were pre-treated with $\tau \eta \varepsilon \mathrm{p} 38$ MAPK inhibitor, SB203580 (25 $\mu \mathrm{M})$, and the ERK1/2 inhibitor, PD98059 $(30 \mu \mathrm{M})$, for $1 \mathrm{~h}$ and exposed to LPS $(1 \mu \mathrm{g} / \mathrm{ml})$ for $20 \mathrm{~h}$. The expression levels of iNOS were then examined by western blot analysis. Data are representative of 3 experiments (means $\pm \mathrm{SD}$ ). ${ }^{\mathrm{H}} \mathrm{P}<0.01$, compared to the vehicle-treated control group. " $\mathrm{P}<0.01$ compared to the group treated with LPS alone.

also examined the I $\kappa \mathrm{B}-\alpha$ levels in the endochylema by western blot analysis. N9 cells were pre-treated with geniposide ( 80 and $160 \mu \mathrm{g} / \mathrm{ml})$ for $18 \mathrm{~h}$ and then co-treated with LPS $(1 \mu \mathrm{g} / \mathrm{ml})$ 

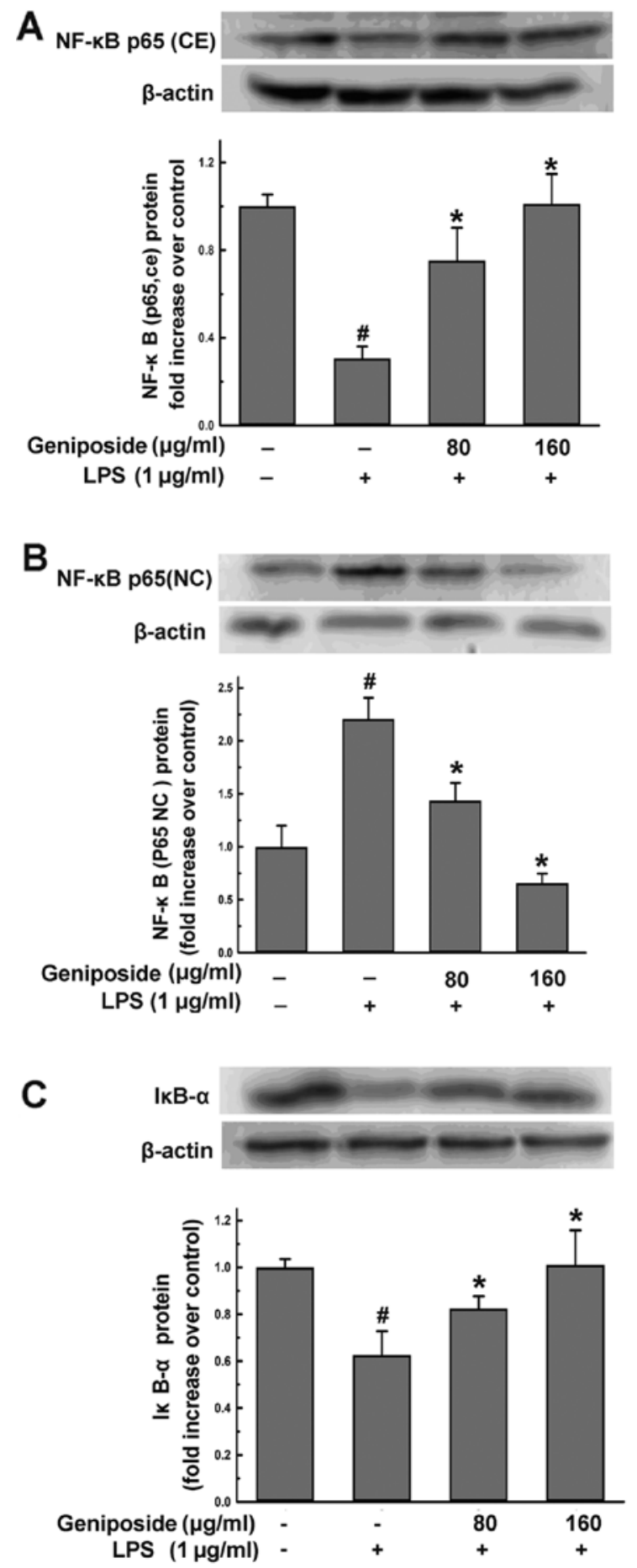

Figure 9. Geniposide inhibited the liberation of $\mathrm{I} \kappa \mathrm{B}$ from the $\mathrm{NF}-\kappa \mathrm{B}$ complex and suppressed the NF- $\mathrm{B}$ translocation into the nucleus induced by LPS in N9 cells. N9 cells were pre-treated with geniposide (80 and $160 \mu \mathrm{g} / \mathrm{ml}$ ) for $18 \mathrm{~h}$ and co-treated with LPS $(1 \mu \mathrm{g} / \mathrm{ml})$ for $6 \mathrm{~h}$. The NF- $\kappa$ B levels in the nucleus and endochylema were examined, and the IкB- $\alpha$ levels in the endochylema were also examined by western blot analysis. Data are representative of 3 experiments (means $\pm \mathrm{SD}$ ). ${ }^{\#} \mathrm{P}<0.05$ compared to the vehicle-treated control group. ${ }^{*} \mathrm{P}<0.05$ compared to the group treated with LPS alone.

for $6 \mathrm{~h}$. The treatment with LPS for $6 \mathrm{~h}$ induced a remarkable downregulation of $\mathrm{NF}-\kappa \mathrm{B}$ in the nucleus and an upregulation of NF- $\kappa \mathrm{B}$ in the endochylema (Fig. 9). By contrast, the intranuclear $\mathrm{NF}-\kappa \mathrm{B}$ protein increased significantly by pre-treatment with geniposide $(80$ and $160 \mu \mathrm{g} / \mathrm{ml})(\mathrm{P}<0.05)$ compared to the LPS-treated groups. Inversely, the levels of NF- $\kappa \mathrm{B}$ in the endochylema decreased markedly $(\mathrm{P}<0.05)$ compared to those of the LPS-treated groups (Fig. 9A and B). During the activation of NF- $\kappa \mathrm{B}$, its inhibitory protein, I $\kappa \mathrm{B}-\alpha$, degraded rapidly in the LPS-treated N9 cells (Fig. 9C). However, IкB- $\alpha$ levels increased significantly by pre-treatment with geniposide $(80$ and $160 \mu \mathrm{g} / \mathrm{ml})(\mathrm{P}<0.05)$. These results indicate that geniposide inhibits NF- $\kappa \mathrm{B}$ activation and the degradation of I $\kappa \mathrm{B}-\alpha$ induced by LPS in N9 cells.

\section{Discussion}

As a type of cell of the macrophage lineage in the CNS, microglial cells are quiescent in the normal brain. However, these cells may be activated by LPS during bacterial infection $(21,22)$. It is well known that the activated microglia produce $\mathrm{NO}$ and pro-inflammatory cytokines, such as TNF- $\alpha$, which alter their cellular functions and initiate an inflammatory cascade associated with several neurodegenerative diseases $(21,23,24)$. To the best of our knowledge, our results demonstrate for the first time that geniposide blocks the underlying pathways of $\mathrm{p} 38, \mathrm{ERK} 1 / 2$ and NF- $\mathrm{B}$ followed by the decrease in ROS, NO and iNOS levels in LPS-treated microglial cells. Our data suggest that geniposide may be beneficial for the treatment of neurodegenerative diseases.

NO is accepted as an active messenger molecule in the cardiovascular and nervous systems. NO is formed endogenously by the conversion of L-arginine to L-citrulline by NOS (25). It has been shown that activated microglial cells kill neurons via NO from iNOS by inhibiting neuronal respiration (26). We found that pre-treatment with geniposide not only inhibited NO secretion, but also suppressed iNOS at both the protein and mRNA levels in LPS-treated N9 cells. This is one of the proposed mechanisms by which geniposide prevents microglial activation induced by LPS.

Quiescent microglia cells are round and small, but LPS-induced microglial cells are disfigured and increase in size, becoming disfigured. The cells pre-treated with various concentrations of geniposide $(20,40,80$ and $160 \mu \mathrm{g} / \mathrm{ml})$ did not become disfigured by LPS treatment (Fig. 4). ROS are normal metabolites of oxidation-reduction reaction in cells, whereas overproduction of ROS induces a series of physiopathological events (27). Based on this fact, the suppression of ROS may be an effective way to protect cells from inflammatory damage. Therefore, we examined the intracellular ROS formation in N9 cells. Our findings clearly showed that geniposide suppressed the production of ROS in a dose-dependent manner. There was no significant cytotoxic effect on cell viability when N9 cells were incubated with geniposide $(1-200 \mu \mathrm{g} / \mathrm{ml})$ for $24 \mathrm{~h}$, implying that the downregulation of NO, iNOS and ROS levels by geniposide was not due to a decrease in cell numbers.

Of note, the effects of geniposide on the downregulation of ROS, NO and iNOS levels in LPS-treated microglial cells occurred through the activation of multiple signaling pathways. We showed that geniposide inhibited the signaling pathways which LPS activated (p38 and ERK1/2 MAPK) by acting on $\mathrm{NF}-\kappa \mathrm{B}$ and $\mathrm{I} \kappa \mathrm{B}-\alpha$. It has been documented that $\mathrm{NF}-\kappa \mathrm{B}$ is a modulator of iNOS expression in microglial cells (28). We found that geniposide remarkably downregulated the increase in phosphorylated levels of p38 MAPK and ERK1/2 in LPS-treated N9 cells. The N9 cells were pre-treated with 
specific MAPK inhibitors, SB203580 against p38 MAPK and PD98059 against ERK1/2, and then the expression of iNOS was determined. It was shown that the inhibitors significantly suppressed the overexpression of the iNOS protein in the LPS-treated N9 cells. These results suggested that the phosphorylation of $\mathrm{p} 38 \mathrm{MAPK}$ and ERK1/2 was attenuated in the suppression of NO, ROS and iNOS by geniposide in LPS-treated N9 cells.

The NF- $\mathrm{KB}$ translocation into the nucleus is preceded by the phosphorylation of IкB- $\alpha$, a protein that normally sequesters the NF- $\mathrm{KB}$ complex in the cytosol in an inactive form. Once phosphorylated, IкB- $\alpha$ undergoes ubiquitination and proteolytic degradation (29). Furthermore, the LPS-induced $\mathrm{NF}-\mathrm{KB}$ activation and subsequent $\mathrm{NO}$ and iNOS production, a pivotal role for $\mathrm{p} 38$ MAPK and ERK1/2, in underlying pathways of microglial cells was examined. Thus, on the basis of our results, it was suggested that geniposide inhibited IкB- $\alpha$ proteolytic degradation and subsequent translocation of NF- $\mathrm{\kappa B}$ into the nucleus.

$\mathrm{AD}$ is an age-dependent neurodegenerative disorder of the cortex and hippocampus, eventually leading to cognitive impairment of the brain. Only a limited number of therapeutic options are currently available to treat this disease. In the present study, we targeted the MAPK-NF- $\mathrm{KB}$ signaling pathway as a novel approach to the management of AD. Geniposide inhibited microglial activation, attenuated ROS production or the production of $\mathrm{NO}$ and the expression of iNOS by blocking $\mathrm{p} 38$, ERK $1 / 2$ and IKB- $\alpha$ activation induced by LPS in N9 cells. These effects of geniposide are significant for suppressing the injury of neurons and preventing and treating several neurodegenerative diseases, such as PD or AD. In this study, we investigated various other signaling pathways and their involvement in the effects induced by geniposide in order to discover additional treatment options for neurodegenerative diseases.

\section{Acknowledgements}

We are grateful for financial support received from the National Nature Science Foundation of China (project no. 81070222) and the Major National Science and Technology Projects of China (project no. 2010ZX09401-306-1-1) and the science and technology innovation ability of construction projects of Chongqing (project no. CSTC, 2010AA5058).

\section{References}

1. Hickey WF and Kimura H: Perivascular microglial cells of the CNS are bone marrow derived and present antigen in vivo. Science 239: 290-292, 1988.

2. Rock RB, Gekker G, Hu S, et al: Role of microglia in central nervous system infections. Clin Microbiol Rev 17: 942-964, 2004.

3. Wilms H, Zecca L, Rosenstiel P, et al: Inflammation in Parkinson's diseases and other neurodegenerative diseases: cause and therapeutic implications. Curr Pharm Des 13: 1925-1928, 2007.

4. Palace J: Inflammation versus neurodegeneration: consequences for treatment. J Neurol Sci 259: 46-49, 2007.

5. Kim YS and Joh TH: Microglia, major player in the brain inflammation: their roles in the pathogenesis of Parkinson's disease. Exp Mol Med 38: 333-347, 2006.

6. Rogers J, Mastroeni D, Leonard B, et al: Neuroinflammation in Alzheimer's disease and Parkinson's disease: are microglia pathogenic in either disorder? Int Rev Neurobiol 82: 235-246, 2007.
7. McGeer PL and McGeer EG: Glial reactions in Parkinson's disease. Mov Disord 23: 474-483, 2008.

8. Qin L, Liu Y, Wang T, et al: NADPH oxidase mediates lipopolysaccharide-induced neurotoxicity and proinflammatory gene expression in activated microglia. J Biol Chem 279: 1415-1421, 2004.

9. Bi XL, Yang JY, Dong YX, et al: Resveratrol inhibits nitric oxide and TNF-alpha production by lipopolysaccharide-activated microglia. Int Immunopharmacol 5: 85-193, 2005.

10. Zhu YM, Azahri NS, Yu D and Woll PJ: Effects of COX-2 inhibition on expression of vascular endothelial growth factor and interleukin-8 in lung cancer cells. BMC Cancer 8: 218, 2008.

11. Saha RN and Pahan K: Regulation of inducible nitric oxide synthase gene in glial cells. Antioxid Redox Signal 8: 929-947, 2006.

12. Akao T, Kobayashi K and Aburada M: Enzymic studies on the animal and intestinal bacterial metabolism of geniposide. Biol Pharm Bull 17: 1573-1576, 1994.

13. Wang SW, Lai CY and Wang CJ: Inhibitory effect of geniposide on aflatoxin B1-induced DNA repair synthesis in primary cultured rat hepatocytes. Cancer Lett 65: 133-137, 1992.

14. Peng CH, Huang CN, Hsu SP and Wang CJ: Penta-acetyl geniposide-induced apoptosis involving transcription of $\mathrm{NGF} / \mathrm{p} 75$ via MAPK-mediated AP-1 activation in C6 glioma cells. Toxicology 238: 130-139, 2007.

15. Liu JH, Yin F, Guo LX, Deng XH and Hu YH: Neuroprotection of geniposide against hydrogen peroxide induced $\mathrm{PC} 12$ cells injury: involvement of PI3 kinase signal pathway. Acta Pharmacol Sin 30: 159-165, 2009.

16. Yamazaki M and Chiba K: Neurotrophic effects of genipin on Neuro2a cells. J Health Sci 51: 687-692, 2005.

17. Nam KN, Choi YS, Jung HJ, et al: Genipin inhibits the inflammatory response of rat brain microglial cells. Int Immunopharmacol 10: 493-499, 2010

18. Mosmann T: Rapid colorimetric assay for cellular growth and survival: application to proliferation and cytotoxicity assays. J Immunol Methods 65: 55-63, 1983.

19. Lantorno M, Chen H, Kim JA, et al: Ghrelin has novel vascular actions that mimic PI 3-kinase-dependent actions of insulin to stimulate production of NO from endothelial cells. Am J Physiol Endocrinol Metab 292: 756-764, 2007.

20. Marcocci L, Maguire JJ, Droy-Lefaix MT and Packer L: The nitric oxide-scavenging properties of Ginkgo biloba extract EGb 761. Biochem Biophys Res Commun 201: 748-755, 1994.

21. Gonzalez-Scarano F and Baltuch G: Microglia as mediators of inflammatory and degenerative diseases. Annu Rev Neurosci 22: 219-240, 1999.

22. Stoll $\mathrm{G}$ and Jander S: The role of microglia and macrophages in the pathophysiology of the CNS. Prog Neurobiol 58: 233-247, 1999.

23. Kreutzberg GW: Microglia: a sensor for pathological events in the CNS. Trends Neurosci 19: 312-318, 1996.

24. Meda L, Cassatella MA, Szendrei GI, et al: Activation of microglial cells by $\beta$-amyloid protein and IFN- $\gamma$. Nature 374: 647-650, 1995.

25. Mayer B, Schmidt K, Humbert P and Böhme E: Biosynthesis of endothelium-derived relaxing factor: a cytosolic enzyme in porcine aortic endothelial cells $\mathrm{Ca}^{2+}$-dependently converts L-arginine into an activator of soluble guanylyl cyclase. Biochem Biophys Res Commun 164: 678-685, 1989.

26. Bal-Price A and Brown GC: Inflammatory neurodegeneration mediated by nitric oxide from activated glia-inhibiting neuronal respiration, causing glutamate release and excitotoxicity. J Neurosci 21: 6480-6491, 2001.

27. Zalba G, Fortuno A, San Jose G, et al: Oxidative stress, endothelial dysfunction and cerebrovascular disease. Cerebrovasc Dis 24 (Suppl 1): S24-S29, 2007.

28. Jung HW, Yoon $\mathrm{CH}$, Park KM, et al: Hexane fraction of Zingiberis Rhizoma Crudus extract inhibits the production of nitric oxide and proinflammatory cytokines in LPS-stimulated BV2 microglial cells via the NF-kappaB pathway. Food Chem Toxicol 47: 1190-1197, 2009.

29. Pahl HL: Activators and target genes of Rel/NF- $\kappa \mathrm{B}$ transcription factors. Oncogene 18: 6853-6866, 1999. 